Abstracta Iranica Abstracta Iranica

Revue bibliographique pour le domaine irano-aryen

Volume 26 | 2005

Comptes rendus des publications de 2003

Structure and Meaning in Medieval Arabic and Persian Poetry. Orient Pearls. London, Routledge Curzon, 2003, 507 p.

Ève Feuillebois-Piérunek

OpenEdition

1 Journals

Édition électronique

URL : http://journals.openedition.org/abstractairanica/1979

ISSN : 1961-960X

Éditeur :

CNRS (UMR 7528 Mondes iraniens et indiens), Éditions de l'IFRI

Édition imprimée

Date de publication : 15 mai 2005

ISSN : 0240-8910

Référence électronique

Ėve Feuillebois-Piérunek, « Structure and Meaning in Medieval Arabic and Persian Poetry. Orient Pearls. London, Routledge Curzon, 2003, 507 p. », Abstracta Iranica [En ligne], Volume 26 | 2005, document 368, mis en ligne le 07 décembre 2005, consulté le 25 septembre 2020. URL : http://

journals.openedition.org/abstractairanica/1979

Ce document a été généré automatiquement le 25 septembre 2020.

Tous droits réservés 


\title{
Structure and Meaning in Medieval Arabic and Persian Poetry. Orient Pearls. London, Routledge Curzon, 2003, 507 p.
}

\author{
Ève Feuillebois-Piérunek
}

1 Première étude occidentale complète et comparative des techniques stylistiques et de composition en poésie médiévale arabe et persane. L'ouvrage étudie successivement trois aspects de la « poétique » orientale : l'invention, la disposition et l'ornementation. La première partie traite de la science des $m a$ (ānī («idées" de la poésie, thèmes poétiques), et des principaux « genres » poétiques (qașida et ġazal).

3 Dans la seconde partie, Julie Meisami s'intéresse aux principes d'organisation structurelle : les parties de la qașida (nasib ou tasrì), madịh, fin ou conclusion, transitions de type Hurūj, taHalluṣ, gurīzgāh), les sous-parties ou unités de sens (fușūl) qui déterminent le schéma général du poème et dont les principes organisateurs sont la proportion et l'équilibre, les variétés de structure, et enfin les adaptations de la qașída.

4 La troisième partie traite des figures rhétoriques, mais l'A. n'entre pas dans le détail des difficultés posées par les traités arabes et persans consacrés à ce sujet (absence de classement des figures, définitions floues, terminologie hésitante). Elle s'intéresse plutôt aux différences dans l'usage de l'ornementation dans les poésies arabe et persane. Alors que la poésie arabe privilégie les figures de mots, la littérature persane s'appuie davantage sur l'imagerie comme principe organisateur.

5 Le livre est abondamment illustré d'analyses détaillées de poèmes arabes et persans traduits en anglais : près d'une trentaine d'auteurs différents y sont représentés.

6 Ce bon travail de synthèse, par les questions pertinentes qu'il pose, incite à la réflexion et ouvre de nombreuses pistes de recherche. 
INDEX

Thèmes : 11.1.1. Littérature persane classique

Keywords : Poésie arabe, poésie persane, Persian poetry, Poésie médiévale, Medieval Poetry, Arabic Poetry

\section{AUTEURS}

ÈVE FEUILLEBOIS-PIÉRUNEK

Sorbonne Nouvelle - Paris III 